\title{
To Join or Not to Join: A Comparative Analysis of Joining or Creating an International Administrative Tribunal
}

\author{
Katherine Meighan and Gabriel Rodríguez-Rico*
}

\begin{abstract}
How well an international organization functions and upholds its privileges and immunities is closely intertwined with the existence of an internal justice system to settle disputes between the institution and its staff. At the apex of such system is the administrative tribunal, mandated to provide final, binding decisions on internal, employmentrelated issues, taking into account the needs of both the international organization and its staff. Some of such international organizations have opted to join and submit to a multi-jurisdictional tribunal, while others have established their own, independent tribunals (arbitration may also be an option, but due to its substantially different nature and procedures, it falls outside the scope of this chapter). This chapter appraises two different scenarios for international organizations: joining a multi-jurisdictional tribunal that receives appeals from various international organizations or establishing a stand-alone tribunal, either independently or in conjunction with other intergovernmental institutions. This assessment provides a brief retrospective of international administrative tribunals, whilst highlighting governance consideration, jurisprudential issues, as well as other operational points that may arise under each option. Although informed by legal advice and other institutional considerations, the final decision is ultimately a political one made by, and in appropriate consultation with, the relevant stakeholders of the international organization (including the membership, the host State, the mandate beneficiaries, and the staff and management of the international organization). So, to join or not to join? There is no right or wrong answer to this question; instead this chapter strives to inform stakeholders when evaluating their options.
\end{abstract}

* Katherine Meighan, General Counsel, Member of Management Team and Legal Advisor to the Governing Council and Executive Board, International Fund for Agricultural Development (IFAD), k.meighan@ifad.org; Gabriel Rodríguez-Rico, Legal Officer, IFAD, j.rodriguezrico@ifad.org. We thank Cynthia Colaiacovo, Deputy General Counsel, IFAD; Rocío Gómez-Sánchez, Head of Corporate Unit, IFAD; Alice Bou Assi and Álvaro Ibares Loncán, our enthusiastic interns at the Office of the General Counsel, for their invaluable input and support in the preparation of this chapter. 
How well an international organization functions ${ }^{1}$ and upholds its privileges and immunities is closely intertwined with the existence of a suitable internal justice system to properly address its needs and those of its staff. ${ }^{2}$ At the apex of that internal justice system is an international administrative tribunal, the ultimate adjudicator, issuing final and binding judgments on employmentrelated matters. As bodies of judicial character, these tribunals adjudicate internal, employment disputes between international organizations and their staff,, ${ }^{3}$ balancing "respect for human rights and the need to eliminate the interference of national courts". ${ }^{4}$ Further, they support organizations in applying administrative actions following principles of equivalent treatment and proportionality for staff, irrespective of their place of recruitment or posting. ${ }^{5}$

The earliest administrative tribunal was established in 1927, merely seven years after the creation of the first modern international organization, the League of Nations. ${ }^{6}$ Since then, such tribunals have multiplied and adjusted to meet the demands of an equally increasing number of intergovernmental institutions. ${ }^{7}$ As part of this evolution, some international organizations have set up their own legal forum, whilst others opted to join one of the tribunals which allow membership of intergovernmental institutions that have not created the tribunal. ${ }^{8}$ Although informed by legal advice, the final decision is ultimately a political one taking into account multiple considerations; further, it is a decision made by and in consultation with the relevant stakeholders of the international organization (including the membership, the host State, the mandate beneficiaries, and the staff and management of the entity).

In this context, it is incumbent upon the relevant stakeholders of international organizations to assess whether it should establish its own tribunal or join a multi-jurisdictional one. This is the case for stakeholders of both new and long-established international organizations, with the latter reviewing

1 ICJ, Effect of Awards 1954, 55-56.

2 International organizations are established under an agreement among their respective member states. These agreements typically grant intergovernmental institutions with privileges and immunities, which generally exempt them from the jurisdiction of national legal systems and courts. Consequently, international organizations rely on their internal justice systems for the adjudication of disputes with their staff rather than submitting them to the purview of local courts and their legal framework.

3 Romano 2011, 248.

4 Amerasinghe, Principles of the Institutional Law of International Organizations 1996, 489.

5 Amerasinghe, 'International Administrative Tribunals in the UN System' 1998, 227.

6 ILO, 9o Years of Contribution 2017, 21.

7 Romano 2011, 241.

8 Amerasinghe, Principles of the Institutional Law of International Organizations 1996, 495. 
periodically whether their respective tribunal continues being the most appropriate legal forum. Whilst some intergovernmental institutions have chosen arbitration for staff dispute resolution, ${ }^{9}$ this option will not be addressed as its nature as a private forum renders it substantially different from the mandate and procedures of an administrative tribunal.

After providing a background overview of such fora, this chapter will examine in turn the complex issues of governance, jurisdiction and operational considerations in both multi-jurisdictional tribunals which admit jurisdiction over multiple international organizations, as well as newly created, standalone tribunals. More specifically, this chapter provides a general overview of international administrative tribunals, based on an assessment on their historic background (Section 2), governance and procedures (Section 3 ) as well as jurisprudence (Section 4) and operational considerations (Section 5 ) on their functioning. (Section 6 offers a conclusion.) The chapter is limited to legal fora issuing final decisions relating to employment-related disputes and does not review mechanisms that may handle preliminary proceedings such as first-instance review boards. This examination of international administrative tribunals does not intend to prefer one option over any other, but rather to provide an overview and analysis of the current landscape for stakeholders evaluating these important questions.

\section{Historic Background of Administrative Tribunals of International Organizations}

In its early jurisprudence, the International Court of Justice (ICJ) stated that "the power to establish a tribunal, to do justice as between the [United Nations] and the staff members, was essential to ensure the efficient working of the [organization]". ${ }^{10}$ While the constituent instruments of most international organizations are silent on the matter of the establishment of an international administrative tribunal, it is nonetheless widely accepted that the authority to determine the appropriate tribunal rests with a governing body of an international organization. ${ }^{11}$

International administrative tribunals are subsidiary organs of judicial character established or recognized by an international organization with the purpose to serve as the ultimate reviewer and arbiter on employment-related

$9 \quad$ Kim and Lee, 19 September 2019.

10 ICJ, Effect of Awards 1954, 57.

11 See as an example the following acts of governance organs of Ios establishing international administrative tribunals: Statute of WBAT; Statute of UNAT; Statute of ILOAT. 
disputes between international organizations and their staff. ${ }^{12}$ For example, the United Nations General Assembly (UNGA), in its capacity as the United Nations' (UN) governing body, established the United Nations Dispute Tribunal (UNDT) and the United Nations Appeals Tribunal (UNAT), both of which are subsidiary UN organs. With this clear role in mind, a survey of existing tribunals reveals a broad spectrum. This comprises long-standing, highly respected tribunals founded 60 to 80 years ago, stand-alone tribunals of international financial institutions often founded 20 to 50 years ago, as well as bodies established as recently as in 2019 at international organizations at a smaller scale.

\subsection{Tribunal as Final Arbiter}

As noted earlier, most international organizations have a first-level, independent review board or similar entity to review employment-related disputes between staff and the intergovernmental institution applying its internal legal framework (that is, the relevant internal regulations, including the international organization's corporate, human resources and related rules, policies and procedures) and generally accepted principles of international administrative law. Should the staff member believe that a first-level decision is not appropriate, ${ }^{13}$ appeal to an international administrative tribunal is normally the next and final recourse, while some tribunals also allow the international organization to submit an appeal. Whilst historically both the UNAT and the Administrative Tribunal of the International Labour Organization (ILOAT) allowed for the possibility of a member organization to request an advisory opinion before the ICJ ${ }^{14}$ UNAT's predecessor abandoned this approach in $1995 .{ }^{15}$ Later in 2016, ILOAT followed suit. ${ }^{16}$ These amendments sought to end the inequality of access to the ICJ between the international organization and its staff members. ${ }^{17}$

As the final arbiter on these issues, UNAT, ILOAT and other such fora study the facts of the matter before them and review the international organization's relevant internal regulations and analysis. There are differences among tribunals in their consideration of the underlying factual record-for example,

\footnotetext{
12 Romano and others 2014, 14.

13 While some first-tier bodies issue independent and binding decisions, others issue recommendations for ultimate decision by the President or Secretary-General of the international organization, as applicable. Amerasinghe, 'Cases of ICJ Relating to Employment in International Organizations' 2009, 201.

15 ILO, 'Amendments to the Statute of ILOAT', 14 June 2016.

16 Ibid.

17 ICJ, Judgments of ILOAT upon Complaints Made Against UNESCO 1956, 85.
} 
some tribunals such as the International Monetary Fund Administrative Tribunal (IMFAT) apply de novo review ${ }^{18}$ to cases while reviewing the relevant factual record established below, ${ }^{19}$ while others such as UNAT and ILOAT consider whether there was a discernible error in the judgment of the first-tier body. ${ }^{20}$ Following the relevant review and analysis, the tribunal then makes the final reasoned decision applying the internal regulations of the respective international organizations under international law. ${ }^{21}$ Thus, the international tribunal is the final arbiter of employment-related disagreements between staff and the relevant international organization.

\subsection{Survey of Long-Existing and Newly Founded Tribunals}

Many international organizations have opted to recognize the jurisdiction of long-standing tribunals which accept external membership. ${ }^{22}$ Within the international legal community, ILOAT and UNAT are the two long-established, highly respected examples. ILOAT is the successor of the Administrative Tribunal of the League of Nations, originally established in $1927,{ }^{23}$ and the functions of which were transferred to the International Labour Organization in $1946 .{ }^{24}$ Meanwhile, UNAT was first established as the United Nations Administrative Tribunal in 1949 until it was substantially reformed in 2009 when it adopted its current title, albeit its acronym has remained. ${ }^{25}$ As discussed further below, given their long-standing nature, these entities have an extensive jurisprudence that has evolved over the decades.

Other international organizations have founded their own independent tribunals. Historically, this trend began with the main international financial institutions establishing stand-alone administrative tribunals including those of the World Bank (1980), the European Bank for Reconstruction and

18 De novo judicial review is used in addressing questions of how the law was applied or interpreted by a lower tribunal. This is a non-deferential standard of review, meaning that the reviewing tribunal applying a de novo review standard does not place weight on (or, absent a clear error, does not defer to) the findings of the previous court. Accordingly, lower tribunal findings under a de novo standard of review may be varied or even overturned by the reviewing tribunal. Other standards of review applied by the appellate or senior tribunal are more deferential, with the senior tribunal placing some weight on the lower tribunal's decisions absent discernible errors therein.

19 IMF, 'IMFAT Reports' 2008, 60.

$20 \quad$ ILOAT, $P$. (No. 2) $v$ WHO 2018, consid 5; UN, 'Appeals and Answers'.

21 Ibid.

22 ILO, 90 Years of Contribution 2017, 25-26; see also ILO, 'Membership'.

23 Uddin and Uddin 2012, 669.

24 ILO, 'ILO Administrative Tribunal'.

25 Reinisch and Knahr 2008, 449 and 482. 
Development, the Asian Development Bank (1991) and the International Monetary Fund (1992). ${ }^{26}$

Over the last decade, it has become apparent that the size of an international organization is not a prerequisite for founding a stand-alone tribunal. While intergovernmental institutions with significant staff numbers, such as the International Organization for Migration, with more than 13,000 staff members, ${ }^{27}$ have decided not to establish their own, ${ }^{28}$ others at a smaller scale have more recently reviewed setting up their own fora. One such example is the 2019 founding of the tribunal of the Technical Centre for Agricultural and Rural Cooperation ACP-EU (CTA), an entity with less than one hundred staff members. ${ }^{29}$ Furthermore, it may be noted that this option could also be carried out jointly by a handful of smaller intergovernmental institutions which share a similar mandate, geographical location or the like.

\section{3}

\section{Governance of Stand-Alone Versus Multi-Jurisdictional Tribunals}

All international administrative tribunals enjoy full independence of judgment, ${ }^{30}$ enabling their impartial review of the relevant law and evidence without improper interference or influence. While ensuring full independence of judgment, tribunals at the same time exercise their powers within the relevant statutes and procedures of their establishment. Accordingly, international organizations which opt to establish their own stand-alone legal forum must generally outline the relevant logistical rules and procedures, as well as cover the concomitant establishment costs. Conversely, those which choose a multijurisdictional body would accede to the procedures of the established governing body of the parent organization and be required to pay fees per case brought before the tribunal and, in some cases, the concomitant costs of yearly membership.

\section{1}

The Stand-Alone Tribunal: a Tribunal Under One's Own Rules

Whilst tribunals have complete independence of judgment on cases brought before them, the back-office and logistical functions of tribunals differ in application for stand-alone versus multi-jurisdictional tribunals. An international

26 World Bank, 'World Bank Administrative Tribunal'; ADB, 'Administrative Tribunal'; IMF, 'IMF Administrative Tribunal'.

27 IOM, 'ІОм Snapshot 2019'.

28 IOM has recognized the jurisdiction of the ILO Administrative Tribunal. See, ILO, 'Membership (ILOAT)'.

29 Statute of the CTA Administrative Tribunal; Council of Europe, 'CTA AT FAQ'.

30 Gomula 1991, 87. 
organization that establishes its own tribunal effectively creates a stand-alone court. As such, the intergovernmental institution has the additional burden of establishing systems, policies and procedures-potentially tackling everything from the required qualification and on-boarding of judges to the mandatory typeface and font of briefs submitted.

At the same time, the international organization may possibly benefit by more nimble and efficient adjustment of the tribunal's processes to the evolving needs of the intergovernmental institution and its staff. Such adjustments might, for example, take into account changes in the international organiztion's size or location, financial and operational capabilities, novel staff or institutional concerns. In this context, the Asian Development Bank and the World Bank amended their tribunals' statutes in $1995^{31}$ and $2009^{32}$, respectively, in order to enhance their independence, allowing the tribunals to manage their budget independently and stating explicitly that they function independently form the management of the respective organizations. Similarly, the Asian Development Bank introduced a second reform in 2006 to discourage actions brought for frivolous reasons or as potential harassment. Specifically, the entity introduced statute amendments to potentially require applicants to pay compensation for a maximum of three years of their base salary when their submission was "without foundation either in fact or under existing law" or "...intended to delay the resolution of the case or to harass the bank or any of its officers or employees". ${ }^{33}$

\subsection{The Multi-Jurisdictional Tribunal: A Tribunal Under the Rules of Others}

An international organization that opts to join a multi-jurisdictional tribunal accedes not only to the relevant jurisprudence (discussed in the next section), but also to the relevant policies, procedures, institutional memory and best practices reflected across the multi-jurisdictional tribunal's legal and operational framework. While such framework may be influenced by the insights of academia, practitioners and the thousands of parties that have been involved in the tribunals' proceedings, multi-jurisdictional tribunals remain nonetheless under the exclusive oversight of their parent international organization's governing body. Hence, in the case of tribunals such as ILOAT and UNAT, any amendment to their Statutes remains under the discretion of the International Labour Conference of the International Labour Organization (ILO), ${ }^{34}$ and the

31 ADB, The Administrative Tribunal of $A D B$ 2012, 78.

32 World Bank, 'Amendments to the Statute of the Tribunal'.

33 Statute of ADBAT, art X(6).

34 Statute of ILOAT, art XI. 
UN General Assembly, ${ }^{35}$ respectively. Moreover, a multi-jurisdictional tribunal may prescribe substantial requirements for the first-tier bodies of the international organizations under its jurisdiction, including on their composition and on the authority who issues the final decision.

As a result, international organizations subject to these tribunals benefit from their long-established legal and operational frameworks, while at the same time having an often broad-ranging consultative role when seeking to initiate or shape potential amendments. Given the high number of hosted participant international organizations, both ILOAT and UNAT provide the benefit of broad consultation with staff and participant institutions before changes are made. Further, given that potential statute amendments fall within the purview of the highest governing body, it may be natural that the process of potential reviews and evolution is a more gradual one for multi-jurisdictional, than for stand-alone, international administrative tribunals.

It is interesting to study, by way of example, the UNAT, which has a long history of reviewing procedures and policies to evolve and adapt as appropriate for staff and participating international organizations. UNAT's predecessor was subject to calls to reform its system since the 1970s in order to, among other things, establish a two-tier system of administrative justice and to foster better representation for staff in disputes with international organizations. ${ }^{36}$ Reviews continued by means of reports and recommendations as late as $2002,{ }^{37}$ and $2005 .{ }^{38}$ Full reform was ultimately approved in 2009 with the establishment of the current UnAT. ${ }^{39}$ This tribunal continues to evolve and adapt to the needs of participant intergovernmental institutions and their staff. For example, in 2000, the UNAT's Statute was amended to require appropriate legal qualifications and experience for its judges, ${ }^{40}$ as a response to concerns that previous judges may have lacked sufficient relevant qualifications. ${ }^{41}$ This was further strengthened in 2005, when the Statute was again amended to specifically require "judicial experience in the field of administrative law or its equivalent". 42

\footnotetext{
35 Statute of UNAT, art 12.

36 Reinisch and Knahr 2008, 473-474.

37 UN, 'Reform of the Administration of Justice' 2002.

38 UNGA RES/59/283, 13 April 2005.

39 Reinisch and Knahr 2008, 482.

40 Ibid, 460; Statute of UN Administrative Tribunal, art 3(1) (as amended by UNGA RES/55/159, 12 December 200o).

41 Pescatore 1994, 236.

42 Gulati 2011, 520.
} 
The 2009 reform further specified a requirement of a minimum number of years for such judicial experience. ${ }^{43}$

Therefore, an intergovernmental institution that subjects itself to a multijurisdictional tribunal will reap the benefits of simultaneously adopting the jurisprudence and long-established procedures of the entity. At the same time, the parent international organization's ongoing review of its legal framework, procedures and practices to best adapt to the evolving needs of staff and participant intergovernmental institutions may be a more gradual process than that of stand-alone international administrative tribunal.

\section{4}

Jurisprudence

This section now turns to considering the jurisprudential ramifications of multi-jurisdictional versus stand-alone international administrative tribunals, in terms of, firstly, 'Foreseeability and Certainty'; and second, 'Standards of Proof and Jurisprudential Consistency'.

\subsection{Foreseeability and Certainty}

Established multi-jurisdictional tribunals such as ILOAT and UNAT have a deep history of over half a century of comprehensive jurisprudence on a wide variety of matters. In a sense, their far-reaching jurisprudence is a blueprint showing the evolution of international administrative law since its creation. This extensive case law serves as reference and guidance to all intergovernmental institutions and their staff, regardless of whether or not they fall under their jurisdiction. By way of example, ILOAT alone has issued over 4,200 judgments and it is now open to more than 58,000 international civil servants from 57 international organizations. ${ }^{44}$

Nevertheless, newly created international administrative tribunals also have some established baseline for their case review. Indeed, the internal law of the international organization itself, both formal and informal, provides a standard for the rights and obligations governing the relationship between the intergovernmental institution and its staff. This includes formal sources such as the articles of agreement and by-laws or other constitutive documents of

43 Statute of UNAT, art 3 ('To be eligible for appointment as a judge, a person shall possess at least 15 years of aggregate judicial experience in the field of administrative law, employment law or the equivalent within one or more national or international jurisdictions. Relevant academic experience, when combined with practical experience in arbitration or the equivalent, may be taken into account towards 5 of the qualifying 15 years'). 
the international organization, as well as its rules and regulations relating to internal human resources, legal and related policies and procedures. Included as a source of this baseline administrative law are related recruitment and other documents, such as the provisions of the appointment letter of the staff member submitting a challenge. ${ }^{45}$ In addition to these formal texts, other sources include the administrative practice of the entity as well as generally accepted principles of international administrative law. Indeed, the commentary to the IMFAT Statute discusses these sources, also indicating that the tribunal should generally not exceed standards of review and limitations applied by other tribunals of international organizations. ${ }^{46}$ To foster a quick database of legal precedents, a new tribunal could also explicitly adopt by reference the generally recognized principles of international administrative law. ${ }^{47}$ Regardless of having adopted by reference other precedents, it is also common practice for a tribunal to support its judgment by referring to the ruling of another international administrative tribunal. ${ }^{48}$ It should be noted, however, that discrepancies remain: for example, while tribunals may rule on the supremacy of general principles of law over an intergovernmental institution's express directives or the language in a letter of appointment, ${ }^{49}$ it remains the case that the interpretation of what constitutes the general principles themselves may vary depending on civil or common law traditions ${ }^{50}$ and the like. ${ }^{51}$

In considering formation of a new tribunal, the jurisprudential foundationincluding precedents and sources of applicable law-should be reviewed to support foreseeability and certainty for staff and the international organization itself in handling disputes. For example, this could impact the manner in which legal practitioners advise their intergovernmental institution on a particular matter, including through settlement, as they may have somewhat more limited resources to predict how the case may develop during litigation. The same issue may also affect staff's view of and expectations regarding a particular dispute-perhaps even fostering excessively high or low expectations given the lack of known precedent. Further, in the event of proceedings, counsel of

\footnotetext{
45 Amerasinghe, 'International Administrative Tribunals' 2014, 317.

46 Commentary on the Statute of IMFAT, art III.

47 See as an example: Statute of ImfAT, art III; Statute of the AfDBT, art v; and EBRD Appeals Procedures, art 3.02.

48 ADB, The Administrative Tribunal of $A D B$ 2012, 80.

49 Ibid, 79.

50 The main difference between the two systems is that common law uses case law as a primary source, whereas in civil law systems, codified statutes predominate.

Powers 2019, 109-112.
} 
staff and the intergovernmental institution alike may find it more challenging to align their legal arguments with the tribunal's precedent and views.

\subsection{Standards of Proof and Jurisprudential Consistency}

Stakeholders of international organizations and legal practitioners should also carefully review the case law of a multi-jurisdiction international administrative tribunal prior to joining it, including matters such as standards of proof and jurisprudential consistency. Understanding that each international organization's governing body may accord varying focus or importance on different elements, this assessment should take into consideration whether the rulings emphasize with appropriate weight and consistency the key institutional issues highlighted by the tribunal's own governing body.

One threshold issue to examine in either joining a multi-jurisdictional tribunal or creating a new international administrative tribunal is the standard of proof to be applied to allegations in the case. For example, one distinction between ILOAT and UNAT is the standard of proof for cases involving potential misconduct. In the former, the tribunal applies a 'beyond reasonable doubt' standard, ${ }^{52}$ while the latter has opted for 'clear and convincing evidence. ${ }^{53}$ Whilst there may be differing applications of these standards in practice, this matter gains relevance in the recent efforts to strengthen institutional tools and mechanisms against all types of harassment, including of a sexual nature. A recent study indicates that a majority of the allegations of harassment at international organizations under the jurisdiction of tribunals that require a 'beyond reasonable doubt' are found to be unsubstantiated as a result of an intergovernmental institution's limited capacity to make a case in the "absence of corroborative or independent evidence of the alleged incident". ${ }^{44}$ This may imply a potential chilling effect on complainants as such a high standard cannot be met due to missing corroborative or independent proof given the nature of these matters. ${ }^{55}$ In contrast, the same study found that 'clear and

$5^{2}$ The 'beyond reasonable doubt' standard is generally considered the highest, most rigorous standard of proof, which requires that no other logical explanation can be derived from the facts except that the staff member committed misconduct. See ILOAT, V. $v$ FAO 2017, consids $7-9$.

The 'clear and convincing' standard of proof generally requires that the evidence being presented must be 'highly' and substantially more probable to be true than untrue. See UNAT, Molariv Secretary-General of the UN 2011, para 30.

54 UNAIDs, 'Report on Prevention of and Response to Harassment' 2018, 44.

55 Ibid, 54 . 
convincing evidence' is a more appropriate threshold in the context of an international organization's investigation powers in light of these allegations. ${ }^{56}$

An assessment of the tribunals' legal precedent should also take into account the manner, consistency and proportionality in which they have interpreted their statutes and rules. When a tribunal has a large number of members with a concomitantly high caseload, it is important to review the consistency of similar judgments based on similar facts across the judicial oeuvre. ${ }^{57}$

The consistency in the interpretations of an international organization's legal framework is also closely related with the renewals and length of the judges' appointments. Indeed, the longer appointments and renewals of a tribunal membership enables it to establish a stronger doctrine and strengthens its rulings. ${ }^{58}$ Similarly, the weight and proportionality of decisions is a crucial factor, particularly regarding certain remedies such as damages and specific performance. These factors may also vary significantly across institutions-both multi-jurisdictional tribunals and stand-alone tribunals. For example, whilst the damages that the UNAT can award are capped at the equivalent of twoyear's compensation of the applicant, ${ }^{59}$ other administrative tribunals such as the one of the Inter-American Development Bank have a one-year compensation cap, except if specific circumstances are met. ${ }^{60}$ This suitability assessment should take into consideration whether the rulings reflect sufficient jurisprudential consistency and an appropriate weight of their decisions based on the matter under its purview, as well as on key issues for the intergovernmental institution.

\section{5 Operational Considerations}

Furthermore, there are a series of operational and logistical support matters with a potential substantial impact for an international organization and its

$56 \quad$ Ibid, 45 .

57 Kryvoi 2015, 288.

58 A conference on international administrative law held in Paris, France, on 16 May 2000 in commemoration of the twentieth anniversary of the World Bank Administrative Tribunal. During the conference, Ibrahim Shihata stated that the renewals of tribunal members 'enabled the Tribunal to establish a doctrine on many issues and to take strong stands in spite of the complexities of the situations that it has had to address'. See Ziadé, Problems of International Administrative Law 2008, Preliminary Materials Xv.

59 UN, 'Administration of Justice' 2004, 3.

6o Statute of IDBAT, art IX $(2)$. 
staff, regardless of whether it establishes its own tribunal or submits to a multijurisdictional international administrative tribunal. This section shall examine three: (i) the secretariat function; (ii) on-boarding and logistical support of tribunal judges; and (iii) the length of time it takes to issue decisions. Most of these aspects would imply additional expenses for a stand-alone tribunal, whilst they are normally included in the cost associated with a multi-jurisdictional tribunal, which require payments on a case-by-case basis and in some cases in addition to an annual retainer fee depending on the number of staff. 61

\subsection{Secretariat}

Establishing a stand-alone international administrative tribunal requires the international organization to review and set up appropriate structural and logistical procedures which themselves align with its diversity of its staff nationalities, its regional versus global missions and the like. Joining an established multi-jurisdictional tribunal requires a similar examination. In this vein, it is crucial for stakeholders to closely analyse the proposed secretariat structure and functioning so as to identify one most suitable to the needs of the individual international organization and its staff from perspectives including confidentiality, information distribution, and requirements for pleadings (including the potential use of multiple official languages).

The establishment of a secretariat or a registrar function requires enabling a back-office information technology system and related procedures that segregate information and assures the highest level of confidentiality due to the sensitive nature of the information. By way of example, such a system should be capable of electronic or mail case-intake from external parties in order to receive submissions from former staff or external attorneys. Rigorous procedures should be established to maintain data privacy and support confidentiality for those concerned. The more sophisticated the system chosen, the larger the likely financial impact on the international organization-particularly one establishing a stand-alone tribunal.

Multi-jurisdictional tribunals have adopted different methods to receive submissions from international organizations and their staff members. Whilst not a strictly legal matter, it would be also advisable to carefully review the different options which may directly impact resources and skills needed, including as to required languages of pleadings and back-office support needed to complete submissions in a timely manner. For example, although the ILOAT employs both French and English as its working languages, it requires the international organization to draft pleadings in the same language in which the

61 ILO, 'Financing of the Tribunal' 2010, paras 3-4. 
staff member initiated the proceedings (that is, French or English) and to submit six hard copies via courier and one in electronic version. ${ }^{62}$ UNAT, on the other hand, allows the intergovernmental institution to conduct submissions in any of the six United Nations official languages (with may result in pleadings by the international organization and the staff member being in different languages) and with solely electronic means of submission. ${ }^{63}$ Although other tribunals, such as the World Bank Administrative Tribunal and the Asian Development Bank Administrative Tribunal, are silent on the matter, "the practice has been to consider English as the official language". ${ }^{64}$ Hence, the official languages of an international organization may not necessarily mirror those of its tribunal. Given the breadth of differences across intergovernmental institutions including varying staff nationalities, working and official languages, regional versus global missions, it is crucial to closely examine the secretariat structure and functioning to identify one most suitable to the individual international organization and its staff.

\subsection{On-Boarding and Logistical Support for Judges}

A new stand-alone tribunal would require its own judges, either selected specifically through an open call or from a roster of renowned experts or a similar exercise. It is considered a best practice to engage seasoned, highly respected jurists with specific legal expertise on employment matters; ${ }^{65}$ the recruitment of such legal professionals with strong experience and objectivity allows them to make robust, seamless contributions to the tribunal.

At the same time, each international organization has a unique mission and manner of operation, as reflected in both its legal framework and its practices. Accordingly, it is not surprising that different international administrative tribunals have tailored requirements for the legal expertise of their judges. For example, the international tribunals of international financial institutions normally select judges with expertise on international civil service and international organization administration; ${ }^{66}$ while UNDT and UNAT require

\footnotetext{
62 Rules of ILOAT, art 8(2).

63 Rules of Procedure of UnAT, art 9(2)(b).

64 Ziadé, 'Some Practical Issues' 2008, 88.

65 Reinisch and Knahr 2008, 460-462.

66 Statute of шват, art IV(1); Statute of АDвAт, art IV(1). Some multilateral development banks now require experience in litigation and/or arbitration; see, for example, EBRD, 'EBRD Administrative Tribunal—Appointment of Judges', 7 September 2016.
} 
experience on national employment law ${ }^{67}$ and ILOAT on appellate judicial expertise. ${ }^{68}$

Whilst a clear separation must be kept between the international organization and the judges to preserve the independence of the latter, a tribunal familiar with its parent organization's rules, policies and procedures may be better suited to determine whether an international organization met its obligations vis-à-vis its staff members. This organizational familiarity can be enhanced through the professional and appropriate on-boarding and logistical support for its independent judges.

A multi-jurisdictional tribunal would absorb the task of supporting its judges; indeed, given the long histories of many such international administrative tribunals, they boast a demonstrated track record of successful on-boarding and logistical support for their roster of judges. However, an international organization that opts to submit itself to this jurisdiction should note that such support would likely be comprehensive and applicable across diverse intergovernmental institutions, rather than tailored to a specific participant international organization. As a result, although the judges will be familiar with the overall system of international organizations, it is likely that they will not be in a position to take into account the nuances and specifics of a responding international organization during proceedings, beyond the information communicated through the pleadings.

On the other hand, an entity that creates its own stand-alone tribunal will not benefit from such a time-tested administrative structure supporting its jurists. Instead, suitable on-boarding and logistical assistance would be needed to support its independent judges to become familiar with the international organization's rules, policies and procedures, as appropriate. While this will involve a financial and time commitment for the international organization, offering such support for judges should enhance their organizational familiarity and ability to operate efficiently within the context. In turn, this should support the jurists' ability to execute their functions in an independent and objective manner to ensure that the international organization meets its obligations vis-à-vis its staff members.

\subsection{Time to Issue Decisions}

The length of time that it takes an international administrative tribunal to review the pleadings, make its analysis and issue the final decision will likely have a substantial impact on the international organization and its staff. As to

$67 \quad$ Elias and Thomas 2012, 164-165.

68 Reinisch and Weber 2004, 103-104. 
the first, the timing will implicate the promptness with which the intergovernmental institution can solve pending matters with staff members and, in the event of an adverse decision, adjust its legal framework. As to the latter, the timing will provide staff members with an outcome to the administrative decision they challenge without undue delay, fostering a sense of fairness and efficiency. Relatively prompt decisions also reduce the time of ambiguity and possibly tension waiting for an outcome, thus supporting a sense of foreseeability and certainty for both staff and the international organization.

Therefore, an international organization that establishes its own standalone tribunal or joins an existing multi-jurisdictional international administrative tribunal, should carefully review the statute of the tribunal as well as the rules of procedures thereof, particularly as to the relevant bureaucratic and logistical considerations that allow for the issuance of prompt judgments. This would normally include the stated maximum timeframes for the various stages of the process including initial pleadings, rejoinders and sur-rejoinders; the timing and logistics for meetings of the tribunal (for example, whether there are oral hearings in which witnesses may be called; whether judges meet in person at a pre-determined number of sessions per year; whether in person or electronic meetings are used; the sufficiency of administrative support and so forth) and the timing for the issuance of decisions. Such procedures would normally be established and periodically reviewed by the judges themselves and set forth in the rules of procedure for the relevant tribunal. The procedures would, of course, be within the overall framework and time limits for issuance of decisions as set forth in the statute of the tribunal itself.

\section{6}

\section{Conclusion}

Evolving over the years since 1927, administrative tribunals of international organizations continue responding to the same need: providing an impartial legal forum to resolve employment-related disputes between staff members and the international organization, whilst upholding institutional privileges and immunities. A diversity of tribunals now exists to address an equally varied number of international organizations with different missions, sizes, operations, practices and legal frameworks.

Throughout the decades, each international organization has answered the question: to join or not to join? While some intergovernmental institutions have opted to join and submit to a multi-jurisdictional tribunal, others have established their own, stand-alone tribunals. Both options allow international 
organizations to provide staff with an independent avenue of review of administrative decisions whilst protecting the privileges and immunities of the international organization. Indeed, this assessment by the relevant stakeholders should take into consideration intrinsic characteristics, institutional commitments and needs of each individual organization and their staff.

International organizations joining an existing multi-jurisdictional international administrative tribunal may benefit from long-established jurisprudence (which may entail more robust certainty and foreseeability), a demonstrated track record of established governance structures (including entities such as a secretariat, registrar, as well as existing on-boarding and back-office support for judges and tribunals) and well-documented procedures and policies. In benefiting from these elements, the participating international organization would of course be required to pay the concomitant costs of yearly membership and fees per case brought before the tribunal which may be more costly than establishing a stand-alone tribunal. Likewise, a multijurisdictional tribunal may adapt its own rules and procedures more gradually to institutional or other changes, and may not have as deep an understanding of the characteristics of each individual participating institution and their staff.

On the other hand, an international organization that establishes its own tribunal effectively creates a stand-alone court. This may allow the international organization to be more nimble and efficient in creating the tribunal and on-boarding judges, and may allow a more tailored approach to the needs of the international organization (for example as to jurisprudential standards, languages of pleadings, time limits, location of any sessions whether in person or via electronic means). Creating a tribunal, though, may also bring with it the additional burden of potentially insufficient jurisprudence, as well as the need to establish governance frameworks (including a secretariat, registrar and support for judges) and also clearly documented policies and administrative support.

This broad-ranging review of international administrative tribunals highlights one consistent factor-namely, that in choosing a tribunal, there is no 'one-size fits all' approach. Whilst informed by legal advice and other considerations, the final decision is ultimately a political one made by the relevant stakeholders of the international organization (including the membership, the host State, the mandate beneficiaries, and the staff and management of the entity). So, to join or not to join? While stakeholders may ultimately choose different options, we argue that their underlying assessment should consider the various complex (and sometimes competing) factors outlined in this 
chapter in light of the key institutional needs, mission and practice of the international organization and its staff.

\section{Reference List}

Amerasinghe C F, 'Cases of the International Court of Justice Relating to Employment in International Organizations' in Lowe V and Fitzmaurice M (eds), Fifty Years of the International Court of Justice: Essays in Honour of Sir Rebert Jennings (1st edn, Cambridge University Press 2009).

Amerasinghe C F, 'Chapter 3: International Administrative Tribunals in the United Nations System' in Dupuy R (ed), Manuel Sur Les Organisations Internationales /A Handbook on International Organizations (2nd edn, Martinus Nijhoff Publishers 1998).

Amerasinghe C F, 'Chapter 15: International Administrative Tribunals' in Romano C and others (eds), The Oxford Handbook of International Adjudication (1st edn, OUP 2014).

Amerasinghe C F, Principles of the Institutional Law of International Organizations (2nd edn, Cambridge University Press 1996).

Asian Development Bank, 'Administrative Tribunal' (АDв) <https://www.adb.org/ about/administrative-tribunal $>$ accessed 15 November 2019 .

Asian Development Bank, The Administrative Tribunal of ADB: 20 Years of Operation (ADB 2012) <https://www.adb.org/sites/default/files/publication/29906/adbadministrative-tribunal.pdf $>$ accessed 14 November 2019 .

Council of Europe, 'CTA AT FAQ' (CoE, 2019) < https://rm.coe.int/faq-about-the-administrative-tribunal-of-the-technical-centre-for-agri/16808defa4> accessed 15 November 2019 .

Effect of Awards of Compensation Made by the United Nations Administrative Tribunal (Advisory Opinion) [1954] ICJ Rep 47.

Elias $\mathrm{O}$ and Thomas $\mathrm{M}$, 'Administrative Tribunals of International Organizations' in Giorgetti C (ed), The Rules, Practices and Jurisprudence of International Courts and Tribunals (Brill Nijhoff 2012).

European Bank for Reconstruction and Development, Appeals Procedures (EBRD) <https://www.ebrd.com/downloads/integrity/appeals.pdf > accessed 5 March 2020.

European Bank for Reconstruction and Development, 'EBRD Administrative Tribunal-Appointment of Judges' (EBRD, 7 September 2016) <https://www.ebrd. com/cs/Satellite $? \mathrm{c}=$ Content $\&$ cid $=1395252395092 \& \mathrm{~d}=$ Mobile $\&$ pagename $=\mathrm{EBRD} \%$ 2FContent\%2FContentLayout $>$ accessed 6 March 2020.

Gomula J, 'The International Court of Justice and Administrative Tribunals of International Organizations' (1991) 13(1) Michigan Journal of International Law 83 
$<$ https://repository.law.umich.edu/cgi/viewcontent.cgi?article=16o8\&context $=$ mjil $>$ accessed 7 January 2020.

Gulati R, 'The Internal Dispute Resolution Regime of the United Nations' (2011) 15(1) Max Planck Yearbook of United Nations Law Online $489<$ https://brill.com/view/ journals/mpyo/15/1/article-p489_12.xml?language=en> accessed 5 March 2020.

International Labour Organization, go Years of Contribution of the Administrative Tribunal of the International Labour Organization to the Creation of International Civil Service Law (ILO, 2017) <https://www.ilo.org/wcmsp5/groups/public/---dgreports/--trib/documents/meetingdocument/wcms_613944.pdf> accessed 8 January 2020.

International Labour Organization, 'Amendments to the Statute of the ILO Administrative Tribunal Adopted' (ILO, 14 June 2016) < https://www.ilo.org/global/ about-the-ilo/how-the-ilo-works/departments-and-offices/jur/legal-instruments/ WCMS_498369/lang--en/index.htm > accessed 15 November 2019.

International Labour Organization, 'ILO Administrative Tribunal' (ILO) <https://www .ilo.org/tribunal/lang--en/index.htm> accessed 19 November 2019.

International Labour Organization, 'Matters Relating to the Administrative Tribunal of the ILO: Financing of the Tribunal' (ILO Programme, Financial and Administrative Committee, 25 October 2010) G B.309/PFA/15<https://www.ilo.org/wcmsp5/groups/ public/---ed_norm/---relconf/documents/meetingdocument/wcms_145943.pdf> accessed 8 January 2020.

International Labour Organization, 'Membership (ILO Administrative Tribunal)' (ILO) < https://www.ilo.org/tribunal/membership/lang--en/index.htm> accessed 15 November 2019 .

International Monetary Fund, 'Commentary on the Statute of the International Monetary Fund Administrative Tribunal' (IMF, 2009) < https://www.imf.org/external/ imfat/pdf/2009_Amended-Statute.pdf\#page=14> accessed 6 March 2020.

International Monetary Fund, 'IMF Administrative Tribunal' (IMF) <https://www.imf .org/external/imfat/index.htm> accessed 15 November 2019.

International Monetary Fund, 'International Monetary Fund Administrative Tribunal Reports Volume III 2003-2004' (IMF, 2008) <https://www.imf.org/external/imfat/ pdf/IMFAT_3.pdf > accessed 17 December 2019.

International Organization for Migrations, 'IOM Snapshot 2019' (IOM, 2019) < https:// www.iom.int/sites/default/files/about-iom/iom_snapshot_a4_en.pdf> accessed 16 November 2019 .

Joint United Nations Programme on Hiv/AIDs (UnAIDs), 'Report on the Work of the Independent Expert Panel on Prevention of and Response to Harassment, Including Sexual Harassment; Bullying and Abuse of Power at UnAIDs Secretariat' (UnAIDS Programme Coordinating Board, 7 December 2018) <https:/www.unaids.org/sites/default/files/media_asset/report-iep_en.pdf $>$ accessed 13 November 2019. 
Judgments of the Administrative Tribunal of the International Labour Organisation upon Complaints Made Against the United Nations Educational, Scientific and Cultural Organisation (Advisory Opinion) [1956] ICJ Rep 77.

Kim J and Lee Y I, 'Where Do International Civil Servants Go for Justice?' (Kluwer Arbitration Blog, 19 September 2019) <http://arbitrationblog.kluwerarbitration.com/2019/o9/19/where-do-international-civil-servants-go-for-justice/? print=print $>$ accessed 8 January 2020.

Kryvoi Y, 'The Law Applied by International Administrative Tribunals: From Autonomy to Hierarchy' (2015) 47 George Washington International Law Review 267.

Molari $v$ Secretary-General of the United Nations, UNAT Judgment No 2011-UNAT-164 (2011).

P. (No. 2) $v$ WHO, ILOAT Judgment No 4032 (2018).

Pescatore P, 'Two Tribunals and One Court-Some Current Problems of International Staff Administration in the Jurisdiction of the ILO and UN Administrative Tribunals and the International Court of Justice' in Blokker N and Muller S (eds), Toward More Effective Supervision by International Organizations: Essays in Honour of Henry G. Schermers (Martinus Nijhoff Publishers 1994).

Powers J, 'The Evolving Jurisprudence of the International Administrative Tribunals: Convergence or Divergence?' in Quayle P and Gao X (eds), Good Governance and Modern International Financial Institutions (АIı Yearbook of International Law, Brill Nijhoff 2019) <https://brill.com/view/book/edcoll/9789004408326/BPooooo6. $\mathrm{xml}>$ accessed 5 March 2020.

Reinisch A and Knahr C, 'From the United Nations Administrative Tribunal to the United Nations Appeals Tribunal-Reform of the Administration of Justice System Within the United Nations' (2008) 12 Max Planck Yearbook of United Nations Law Online 447 <https://www.mpil.de/files/pdf3/mpunyb_13_knahr_12.pdf.> accessed 5 March 2020.

Reinisch A and Weber U A, 'In the Shadow of Waite and Kennedy: The Jurisdictional Immunity of International Organizations, the Individual's Right to Access to the Courts and Administrative Tribunals as Alternative Means of Dispute Settlement' (2004) 1(1) International Organizations Law Review 59.

Romano C, 'A Taxonomy of International Rule of Law Institutions' (2011) 2(1) Journal of International Dispute Settlement 241.

Romano $\mathrm{C}$ and others, 'Chapter 1: Mapping International Adjudicative Bodies, the Issues, and Players' in Romano C and others (eds), The Oxford Handbook of International Adjudication (1st edn, OUP 2014).

Rules of Procedure of the United Nations Appeals Tribunal (UNAT) $<$ https://www .un.org/en/internaljustice/pdfs/2019-01-11-UNAT-rules-of-procedure.pdf> accessed 5 March 2020. 
Rules of the Administrative Tribunal of the International Labour Organization (ILOAT) <https://www.ilo.org/tribunal/about-us/WCMS_249195/lang--en/index.htm> accessed 5 March 2020.

Statute of the Administrative Tribunal of the African Development Bank (AfDB Administrative Tribunal) <https://www.afdb.org/fileadmin/uploads/afdb/Documents /Administrative-Tribunal/Statute_of_the_Administrative_Tribunal_-_MAJ.pdf> accessed 5 March 2020.

Statute of the Administrative Tribunal of the Asian Development Bank (ADBAT) <https://www.adb.org/sites/default/files/institutional-document/33394/statute -adb-tribunal.pdf> accessed 5 March 2020.

Statute of the Administrative Tribunal of the Inter-American Development Bank Group (IDBAT) <http://idbdocs.iadb.org/wsdocs/getdocument.aspx?docnum=39458925> accessed 5 March 2020.

Statute of the Administrative Tribunal of the International Labour Organization (ILOAT) <https://www.ilo.org/tribunal/about-us/WCMS_249194/lang--en/index.htm> accessed 5 March 2020.

Statute of the Administrative Tribunal of the International Monetary Fund (IMFAT) <https://www.imf.org/external/imfat/statute.htm> accessed 5 March 2020.

Statute of the Administrative Tribunal of the Technical Centre for Agricultural and Rural Cooperation (CTA Administrative Tribunal) <https://rm.coe.int/statute-ofthe-administrative-tribunal-of-the-technical-centre-for-agr/16808defa2 > accessed 5 March 2020.

Statute of the Administrative Tribunal of the United Nations (UN Administrative Tribunal) <https://untreaty.un.org/UNAT/Statute.htm> accessed 5 March 2020.

Statute of the United Nations Appeals Tribunal (UNAT) <https://www.un.org/en/internaljustice/unat/unat-statute.shtml $>$ accessed 5 March 2020.

Statute of the World Bank Administrative Tribunal (WBAT) <https://tribunal.world bank.org/statute> accessed 5 March 2020.

Uddin M K and Uddin M S, 'The Contractual Rights of International Civil Servants: Administrative Tribunals of the United Nations and International Labour Organization Perspective' (2012) 3(11) Mediterranean Journal of Social Sciences 667.

United Nations, 'Administration of Justice: Harmonization of the Statutes of the United Nations Administrative Tribunal and the International Labour Organization Administrative Tribunal' (UN Joint Inspection Unit, 2004) < https://www.unjiu.org/ sites/www.unjiu.org/files/jiu_document_files/products/en/reports-notes/JIU\%2o Products/JIU_REP_2004_3_English.pdf> accessed 5 March 2020.

United Nations, 'Appeals and Answers' (UN) < https://www.un.org/en/internaljustice/ unat/appeals-and-answers.shtml $>$ accessed 17 December 2019. 
United Nations, 'Reform of the Administration of Justice in the United Nations System: Options for Higher Recourse Instances' (UN Joint Inspection Unit, June 2002) <https://www.unjiu.org/sites/www.unjiu.org/files/jiu_document_files/products/en/reports-notes/JIU\%2oProducts/JIU_REP_2002_5_English.pdf > accessed 6 March 2020.

United Nations General Assembly RES/55/159 (12 December 2000) UN Doc A/RES/55/159.

United Nations General Assembly RES/59/283 (13 April 2005) UN Doc A/RES/59/283. V. $v$ FAO, ILOAT Judgement No 3880 (2017).

World Bank, 'Amendments to the Statute of the Tribunal' (World Bank) $<$ https://tribunal.worldbank.org/news/amendments-statute-tribunal-o> accessed 19 November 2019 .

World Bank, 'World Bank Administrative Tribunal' (World Bank) <https://ribunal. worldbank.org/> accessed 15 November 2019.

Ziadé N (ed), Problems of International Administrative Law (Martinus Nijhoff Publishers 2008).

Ziadé N, 'Some Practical Issues Arising in International Administrative Tribunals' in Ziadé N (ed), Problems of International Administrative Law (Martinus Nijhoff Publishers 2008). 